\title{
AC 2009-1810: AN INNOVATIVE MODEL FOR TEACHING COMMUNICATION SKILLS IN ENGINEERING CURRICULA
}

\section{Warren Hull, Louisiana State University, Baton Rouge}

Warren R. Hull, Sr. is the Engineering Communications Coordinator at Louisiana State University. He earned a B.S. in Mechanical Engineering from Louisiana State University and an M.S. in Environmental Health from Harvard University. His engineering career spans over 40 years. He is a licensed Professional Engineer who was previously an engineering consultant, and is also a retired military officer.

\section{Warren Waggenspack, Louisiana State University, Baton Rouge}

Warren N. Waggenspack, Jr. is currently the Associate Dean for Engineering Undergraduates and holder of the Ned Adler Professorship in Mechanical Engineering at Louisiana State University. He obtained both his baccalaureate and master's degrees from LSU ME and his doctorate from Purdue University's School of Mechanical Engineering. He has been actively engaged in teaching, research and curricula development since joining the faculty in 1988.

\section{Lillian B Bowles, Louisiana State University, Baton Rouge}

Lillian Bridwell-Bowles is a Professor of English at Louisiana State University and Director of Communication across the Curriculum $(\mathrm{CxC})$. She received her baccalaureate and master's degrees from Florida State University and her doctorate from the University of Georgia. She has published many articles and books on writing in various disciplines, led a number of successful grants on communication in technical fields, and served as the Chair of the Conference on College Composition and Communication. She was previously a member of the faculty at the University of Minnesota.

\section{David Bowles, Louisiana State University, Baton Rouge}

David Bowles is a Technical Communication Instructor in the Engineering Communication Studio at Louisiana State University. He earned a baccalaureate degree in English and a Master of Fine Arts in Creative Writing from Virginia Commonwealth University. He is a former assistant editor of Blackbird: an online journal of literature and the arts, and his writing has appeared in a variety of magazines, including River Oak Review, Rainbow Curve, and Red Rock Review.

\section{Tiffany Walter Choplin, Louisiana State University, Baton Rouge}

Ms. Choplin is a Technical Communication Instructor in the Engineering Communication Studio at LSU. She earned a bachelor of arts in English and Political Science from the University of Kansas, a master's degree of English from the University of Kansas, and is currently finishing her $\mathrm{PhD}$ in English from Louisiana State University. Her primary areas of research include examining the intersection of pedagogical reform in higher education with writing- or communicating-to-learn principles. 


\title{
An Innovative Model for Teaching Communications Skills In the Engineering Curriculum
}

\author{
Key Words: Communication, ABET, Recognition, Assessment
}

\begin{abstract}
In 2005, two events occurred that provided the university with an opportunity to create an innovative model for teaching communication skills in the undergraduate engineering curriculum. The first was a restructuring of the English department resulting in the loss of substantial number of instructors who had taught lower-level composition courses. This made it difficult for our engineering students to obtain technical writing skills demanded by ABET and prospective employers. The second was the creation of a campus-wide communication initiative enabled by a grant from a generous alumnus. A key element of this program dictated that communication skills be integrated into existing courses in the various disciplines. During the ensuing three years, these two events have evolved into an innovative, sustainable model that has yielded substantial benefits for our university, the engineering faculty, and our students.

At the start of our initiative, reservations voiced include such concerns as loss of technical content in the engineering course, workload increase for both students and engineering faculty, and value of results. Meeting these concerns required the development of an intensive workshop for designated faculty, creation of a facility staffed with dedicated professionals and equipped with specialized equipment, and other support mechanisms.

Analysis has shown that the university's investment in the various elements of our current program compare quite favorably with the costs associated with the number of instructors previously used in teaching writing. Looking beyond the fiscal comparisons, it has been observed that a significant number of additional benefits accrued with this model integrating communication into designated engineering courses of each department. Whereas the previous model focused only on writing, this new approach takes a broader view of communication including an oral and a visual element. Rather than being taught as a general education course across campus, the integrated format for teaching these skills now engages the engineering faculty in a collaborative environment with resources drawn from within the College of Engineering.
\end{abstract}

We have used a variety of approaches to assess the success of our initiative, including student evaluations, faculty survey, and an external advisory council. Our initial observations, drawn over a three-year period in Senior Capstone Courses, are that students' understanding of the technical content has increased in the communication-intensive courses. It seems that students' efforts to communicate technical aspects of their designs, have required better understanding of these aspects, especially when the students are challenged during their oral presentations. Feedback from design review panels and external advisory councils during this same timeframe have been consistently confirming increases in the quality of communication skills for our graduates. These positive results are complemented by data drawn from in house surveys that have clearly shown positive acceptance of this model by both faculty and students. 


\section{Introduction}

The Engineering Accreditation Commission of the Accreditation Board for Engineering and Technology (ABET) outcomes-based accreditation initiative (Engineering Criteria 2002)1 Criterion 3 under "Program Outcomes and Assessment," emphasized the necessity for engineering graduates to demonstrate the ability to communicate effectively. The engineering education community also embraced other sources citing the importance of effective communication skills in the current and evolving engineering environment. One of these has been the feedback received from employers of engineering school graduates. The National Association of Colleges and Employers (NACE), in their Job Outlook 2009², lists good communication skills as the number one personal quality employers look for in college graduates. For years, Boeing has posted the "Desired Attributes of an Engineer"3 on its website, which include "good communication skills: written, oral, graphic, and listening." However, the need for better communication skills is not limited to the needs of American companies. The latest US Department of Labor Occupational Outlook Handbook ${ }^{4}$ reiterates the need for expanded communication skills, and goes on to suggest that the rise of the Internet causes a decline in the demand for US Engineers, but cites communication skills as a means for US Engineers to remain in demand.

Knowing that adding communication emphasis is essential presents two challenges for most engineering programs: (1) What teaching resources will be used, and (2) How does it fit into an already demanding curriculum. At Louisiana State University (LSU), these two issues converged as a result of an unexpected circumstance and a new opportunity.

\section{The Unexpected Circumstance}

The unexpected circumstance LSU encountered was the growth of non-Ph.D. instructors in the English Department to meet the demands of growing enrollment. This was viewed as an undesirable situation for a major research university; therefore, it was deemed necessary to reduce the large number of graduate assistants and non-tenured instructors. Of course, this required major restructuring of the English Department, which phased out the technical writing courses being offered. Since engineering relied upon these courses for all of its disciplines, this forced a re-thinking of how students would receive this type of skill.

The loss of technical writing was not met with a sense of loss of historic proportions because there had been many engineering faculty members who had already questioned the value of this resource. Among the issues raised were:

- $\quad$ Return on investment. With an average of 8 sections per semester in the English Department committed to teaching technical writing, one had to wonder whether the university was getting a commensurate return for its investment in these instructors.

- $\quad$ Consistency of teaching. College of Engineering (COE) faculty who assigned written work in their courses observed that some students showed stark deficiencies in their grasp of technical writing, even after successful completion of the technical writing course.

- Engineering faculty engagement. With the large number of instructors teaching these courses, and the fact that they resided in another college, many COE faculty felt that they 
had little input to the curricular requirements. It must also be observed that a majority of engineering faculty members do not feel that it is their role to dictate writing requirements in these courses.

- $\quad$ Only one communication skill addressed. As the name implies, the focus of these courses was entirely on the written communication skills. This is the most significant limitation. Oral communication was typically addressed as an elective course, requiring students to choose any one of several speech electives.

\section{The Fortuitous Opportunity}

At approximately the same time that the English Department was restructuring, a now-deceased alumnus provided the university with a gift for the purpose of establishing a university-wide program that would focus on improving students' communication skills. The donor's primary interest was to accomplish this task in engineering classes first; however, from the beginning, he envisioned this program as a means of addressing student needs across all curricula. This campus-wide program was designated the Communication across the Curriculum $(\mathrm{CxC})$ program. Four components of $\mathrm{CxC}$ that are critical to endorsement and adoption by faculty and students in the COE are described below:

Summer Faculty Institutes. The first step in integrating specific communication skills into the $\mathrm{COE}$ was to identify a core faculty group representing each of the departments. This core group of eleven faculty members prepared for a leadership role in the communication project by attending a $\mathrm{CxC}$-sponsored Faculty Institute during the summer of 2005. The engineering team received a comprehensive orientation to the campus-wide $\mathrm{CxC}$ program and explored how their participation could lead to the integration of communication goals in the COE curriculum. They worked on their individual syllabi, as well as college-wide plans for a COE Communication Studio. They shared their ideas about an engineering graduate's need for communication skills and their newly-revised syllabi with faculty members representing all colleges, who provided an interdisciplinary audience for their perspectives. In many cases, the necessary communicationbased work already existed within the course, so it merely had to be adapted to meet $\mathrm{CxC}$ requirements.

In 2006, the CxC Faculty Institute hosted 33 faculty participants, with engineering faculty comprising the majority. The focus of the 2006 Summer Institute was on assessment strategies in the four communications modes: oral, written, visual, and technological. Not only did participants explore assessment strategies and rubric design, they also learned ways to integrate iterative assessment effectively throughout the course of a project and a semester.

Engineering Communication Studio. During the fall of 2005, the first of several planned Communication Studios opened on campus. These studios are intended to be integrated into various university colleges and built around a disciplined theme relevant to each specific college. In engineering, the central theme is facilitating group communication dynamics, such as are central to a design team. The Engineering Communication Studio (Studio) has state-of-the-art technology applications at 17 computer work stations and comfortable lounge seating for an Internet café atmosphere. With its movable seating, this area is also heavily used for small group discussions of team projects. The Studio also features a conference room equipped with a 
SmartBoard ${ }^{\mathrm{TM}}$ and video recording to enable students to develop, practice and review oral presentations.

\section{Figure 1- Studio Conference Room}

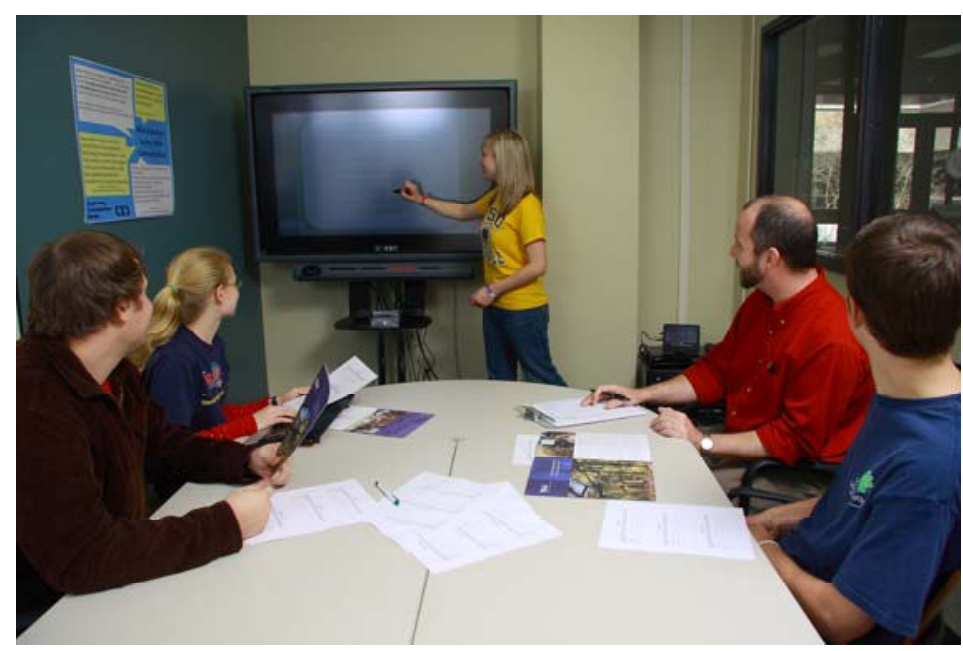

Figure 2 - Studio Lounge Area and Workstations

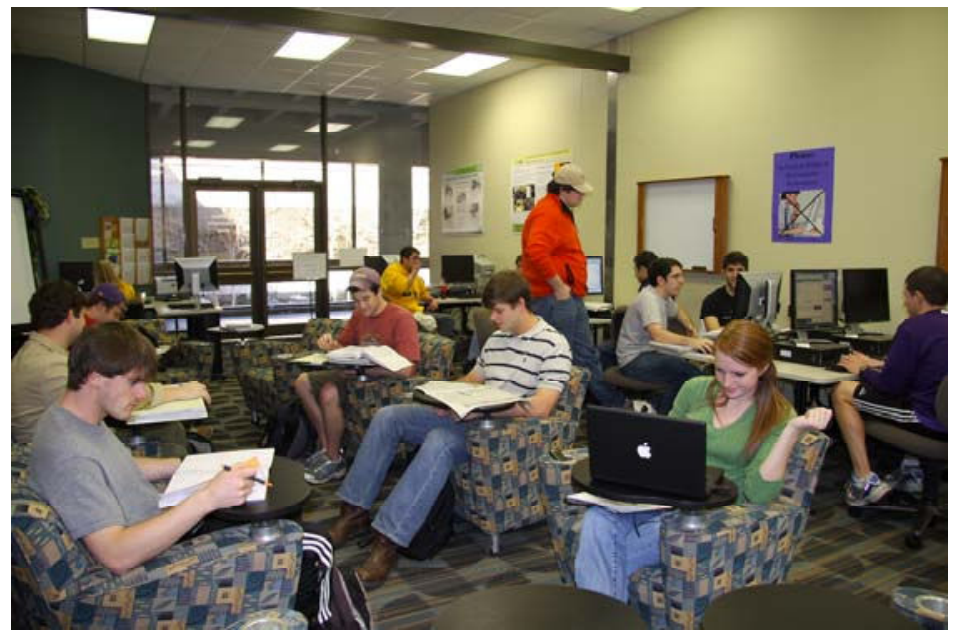

To support students and faculty, the Studio is staffed with a Communication Coordinator and two Communication Instructors. These three professionals work directly with students and faculty to enhance students' written, oral, visual, and technological communication skills. The support for faculty ranges from assisting in the development of course syllabi that integrate communication components to developing rubrics for assessing critical skills and providing classroom instruction on communication-specific topics. This cooperative relationship often leads to faculty referring students to the Studio instructors for individual and team tutorials. It is not lost on the students that the instructors are familiar with the course content and goals; therefore, students perceive the tutorials as being more relevant and having a more immediate impact upon their academic performances than stand-alone courses or tutorial programs outside the COE. 
Communication-Intensive Courses. Courses that focus on any two of CxC's four communication emphases — written, oral, visual, and technological—can be certified as Communication-Intensive (C-I) courses. Faculty can review C-I course requirements on the $\mathrm{CxC}$ website and then submit documentation via that website to receive the $\mathrm{C}$-I designation. For example, senior design courses require students to produce written reports and deliver oral presentations. Faculty members teaching these courses give students direct feedback on assignments, which the students then have an opportunity to revise. These courses also emphasize the informal, generative portions of the creative process, such as brainstorming and prewriting in design notebooks. During the 2007/2008 academic year, C-I courses were taught in each of engineering disciplines. These courses ranged from first-year introductory courses to capstone courses. In fact, each of the capstone courses across the COE received the C-I designation.

Distinguished Communicator. In addition to the Engineering Communication Studio and C-I courses offered throughout the $\mathrm{CoE}$, in 2006 , the $\mathrm{CxC}$ program offered students the opportunity to be recognized as LSU Distinguished Communicators (D-Comms) based on exemplary levels of communication skills developed over their undergraduate years. Students who complete the rigorous requirements are identified as "LSU Distinguished Communicators" on their transcripts and also recognized at commencement. To meet the D-Comm requirements, students must complete at least 12 credit hours of C-I courses, assemble a digital portfolio showcasing their communication skills, have their portfolios approved by designated academic advisors, and show evidence of leadership on campus and in the community. In the inaugural spring of 2006, 7 of the 8 recipients of LSU Distinguished Communicators came from the CoE. Of the $33 \mathrm{D}-\mathrm{Comms}$ recognized at LSU through fall 2009, 19 have been engineering graduates.

\section{Figure 3 - 2007 LSU Distinguished Communicators with Recognition Medals Awarded at Graduation}

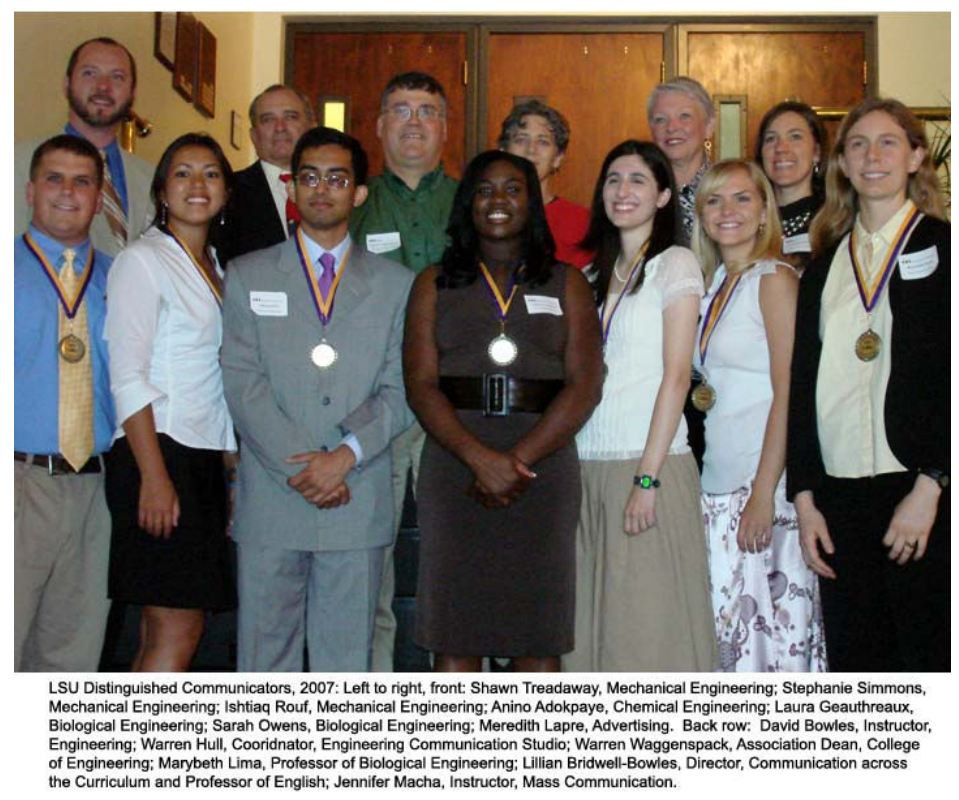




\section{Attractive Features of the Current Model}

Although precipitated by an unexpected event, the current model has yielded benefits that reach well beyond that which was offered by a single technical writing course. Some of these are discussed below; however, even more returns are being discovered as the experience continues.

Reaching far more students comprehensively. While a single required technical writing course could conceivably capture each student, this one-semester exposure pales in comparison to the broad range of C-I courses that COE students are now experiencing. This collection of courses assures that communications skills are taught and reinforced over much of the students' undergraduate experience. Table 1 illustrates the range of C-I courses and total number of students enrolled during the 2007-2008 academic year.

\section{Table 1. Engineering C-I Courses Taught}

\begin{tabular}{|c|c|c|c|}
\hline \multicolumn{2}{|l|}{ FALL 2007} & \multicolumn{2}{|l|}{ SPRING 2008} \\
\hline Course & \# Students & Course & \# Students \\
\hline Biological Engineering 1250 & 67 & Biological Engineering 1252 & 59 \\
\hline Chemical Engineering 4162 & 17 & Biological Engineering 4290 & 42 \\
\hline $\begin{array}{l}\text { Civil and Environmental } \\
\text { Engineering } 3410\end{array}$ & 15 & Chemical Engineering 4162 & 27 \\
\hline $\begin{array}{l}\text { Civil and Environmental } \\
\text { Engineering } 4750\end{array}$ & 40 & $\begin{array}{l}\text { Civil and Environmental } \\
\text { Engineering } 3410\end{array}$ & 25 \\
\hline Construction Management 1010 & 96 & $\begin{array}{l}\text { Civil and Environmental } \\
\text { Engineering } 4750\end{array}$ & 30 \\
\hline Construction Management 1020 & 68 & Construction Management 1010 & 96 \\
\hline Construction Management 3000 & 96 & Construction Management 1020 & 64 \\
\hline Construction Management 3506 & 65 & Construction Management 3000 & 96 \\
\hline Electrical Engineering 4701 & 7 & Construction Management 3506 & 90 \\
\hline Engineering 1050 & 100 & Construction Management 4200 & 60 \\
\hline Industrial Engineering 4599 & 10 & Mechanical Engineering 2212 & 44 \\
\hline Mechanical Engineering 2212 & 64 & Mechanical Engineering 4202 & 84 \\
\hline Mechanical Engineering 4243 & 83 & Mechanical Engineering 4611 & 79 \\
\hline Mechanical Engineering 4621 & 76 & Petroleum Engineering 4999 & 46 \\
\hline Petroleum Engineering 4998 & 46 & & \\
\hline Petroleum Engineering 4999 & 10 & & \\
\hline Semester Student Total & 860 & Semester Student Total & 842 \\
\hline & & 2007-2008 Year Total & 1702 \\
\hline
\end{tabular}

Additional communication skills taught. All C-I courses require that at least two communication skills be included in the course requirements, therefore, expanding the skill set well beyond the written mode. For assessment purposes, the university polled students via a questionnaire at the conclusion of each C-I course. One question asked was, "Of the following "flavors", with which ones do you need more help? Fill all that apply." Student responses are shown in Figure 4. 
Figure 4 - Fall 2007 and Spring 2008 Student Responses

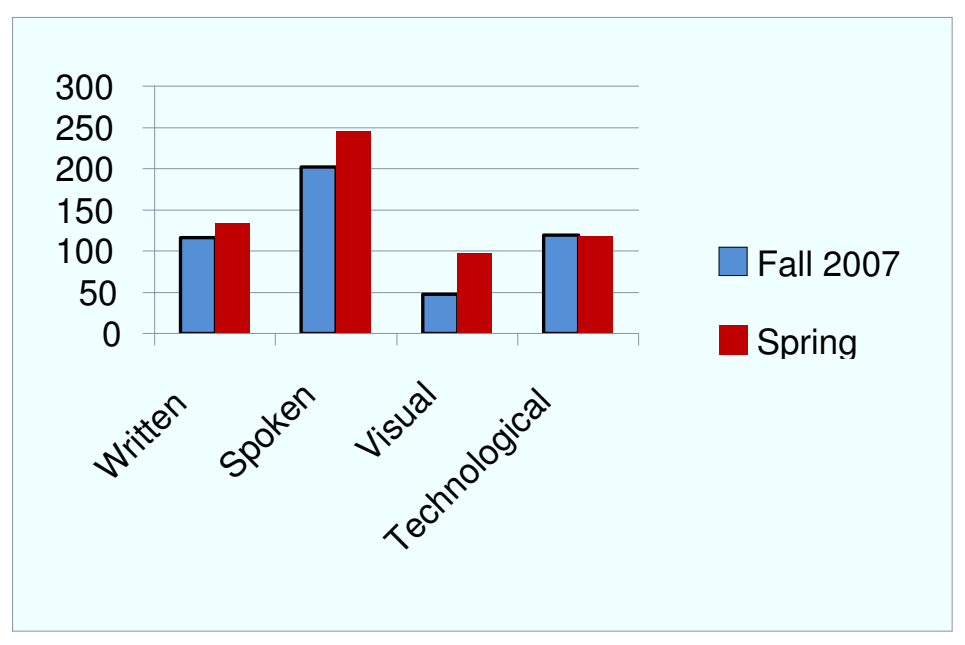

Engineering faculty members engaged. COE faculty members use syllabi that they have adapted to incorporate communication skills. Although they concede that it does require additional work, assessment of faculty attitudes shows that they typically believe the students have learned course content at a higher level.

Alternative learning environment. The Engineering Communication Studio (ECS) has become a popular environment for the students, contributing to a growing sense of community and camaraderie. Based on the usage numbers in Table 2 shown, the ECS serves nearly half of the roughly 2000+ upper level students in the Engineering senior college.

- $\quad$ The ECS is a more flexible workspace than a traditional classroom

- $\quad$ The ECS has more resources available to students than a traditional classroom (technology, one-on-one help for a range of communication needs, etc.)

- $\quad$ The ECS maintains higher profile among engineering students than other service-oriented campus entities (i.e., Writing Center, START, student organizations, etc.)

- $\quad$ The ECS acts as a portal for other academic and enrichment programs (chiefly through Distinguished Communicator, Dports, service learning, etc.)

- $\quad$ The ECS serves as environment for many mentoring and tutoring transactions (peer-to-peer mentoring, CoE sponsored tutoring sessions, informal mentoring sessions)

Table 2. Engineering Communication Studio Student Use Comparisons

\begin{tabular}{|r|c|c|c|}
\hline Students & Spring 2007 & Spring 2008 & \% Increase \\
\hline Number of Users & 688 & 931 & $35 \%$ \\
\hline Total Number of Visits & 3746 & 4914 & $31 \%$ \\
\hline Hours Spent in Studio & 5497 & 7746 & $41 \%$ \\
\hline
\end{tabular}




\section{Assessment of Results}

A survey of faculty who had taught a C-I course (2007-2008) yielded the results shown in the following figures.

Figure 5 - The preparation time involved in teaching a C-I course is comparable to similar courses without the $\mathrm{C}$-I designation.

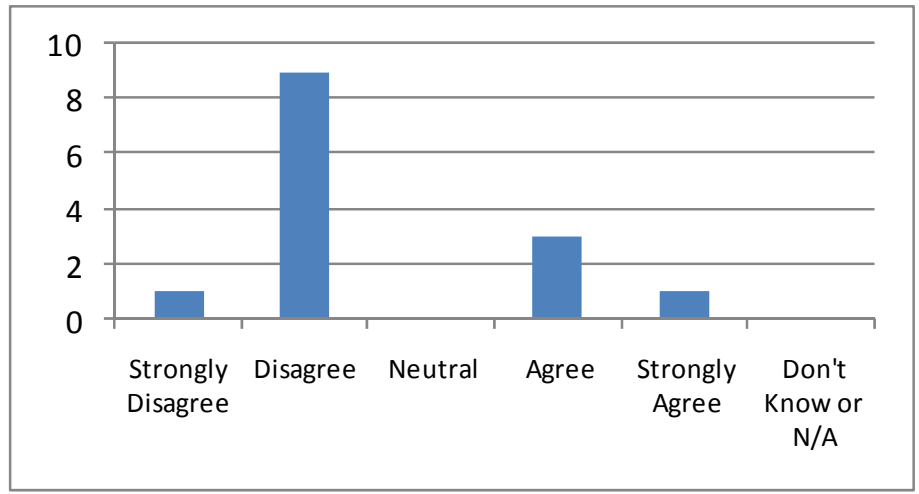

Figure 6 - Course content was not sacrificed in order to meet the communication requirements for $\mathrm{C}$-I designation.

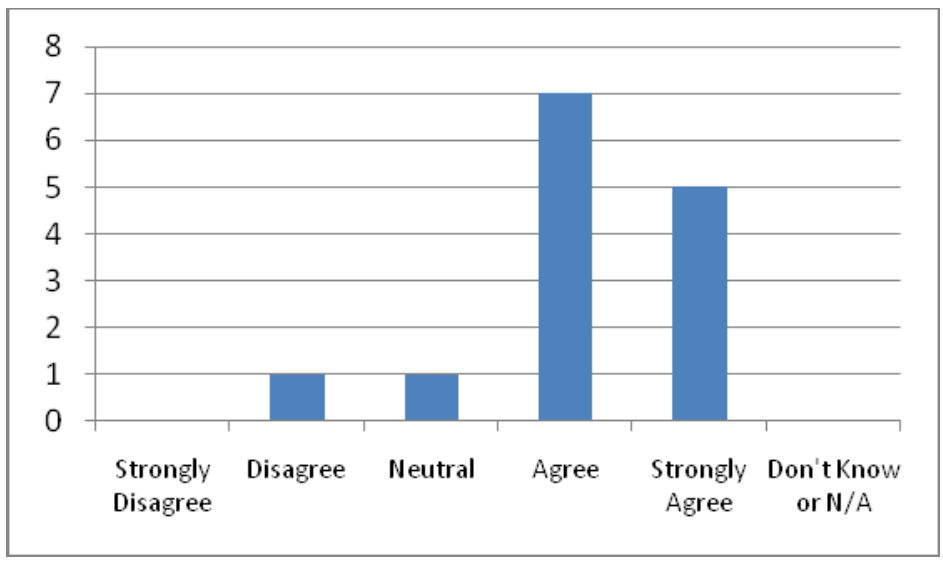


Figure 7 - The student workload involved in taking a C-I course is comparable to similar courses without the $\mathrm{C}$-I designation.

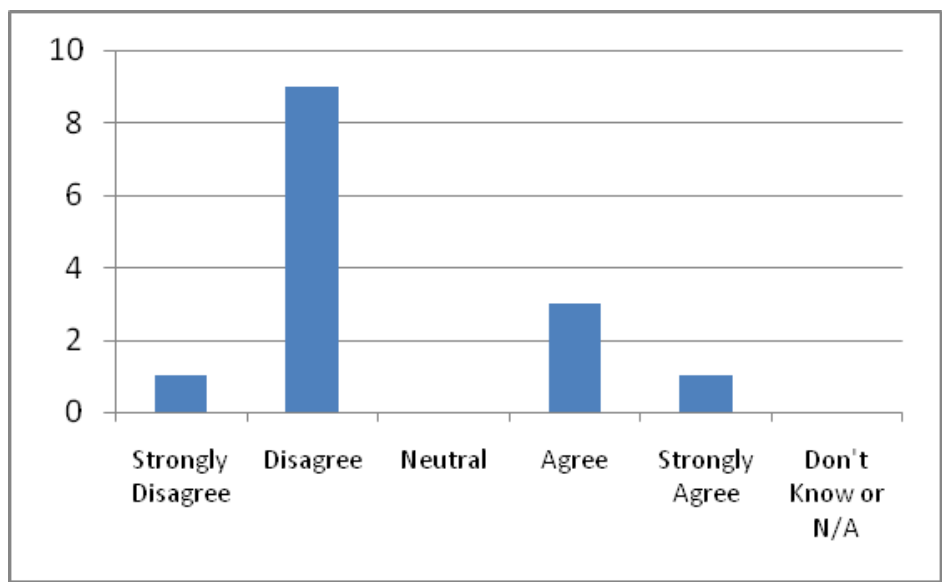

Figure 8 - Student communication skills improved noticeably by the end of my $C$-I course.

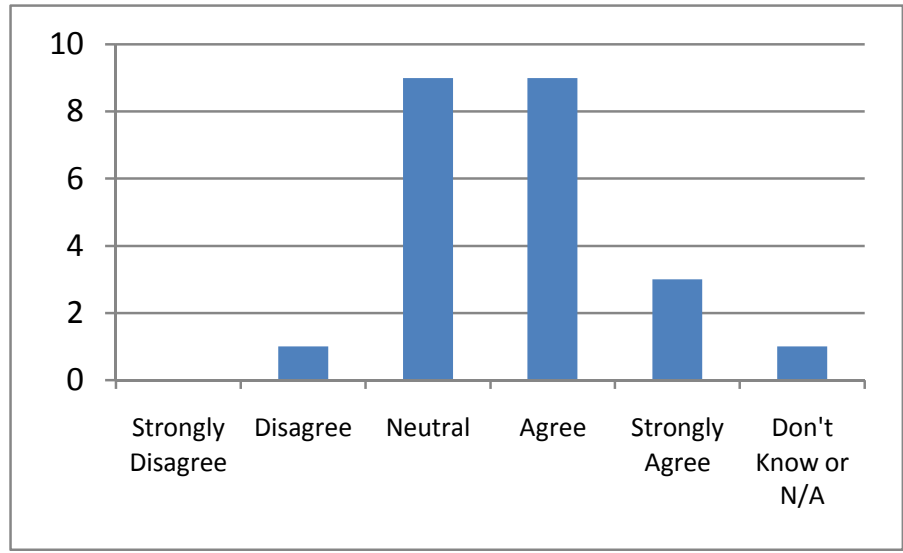


Figure 9 - Students learned the course content in more depth because of the communication requirements.

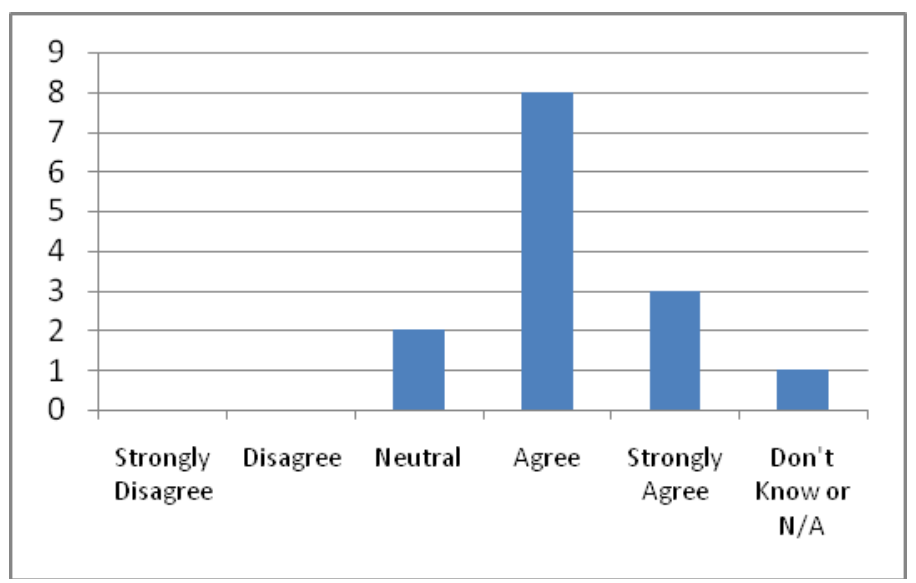

As mentioned previously, the university surveyed students completing C-I courses via a questionnaire. The following summarizes their responses:

Figure 10 - Fall 2007 and Spring 2008 student responses to question, "How much did the communication assignments in this course help you to improve your communication skills?"

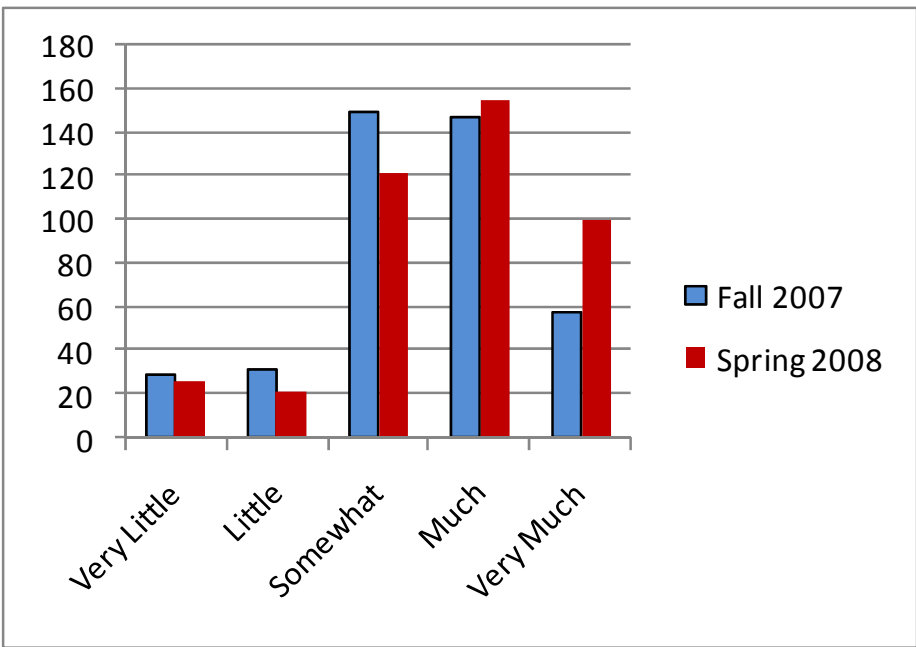


Figure 11 - Fall 2007 and Spring 2008 student responses to question, "How likely are you to use what you learned about communication in this course as you work on future communication projects?"

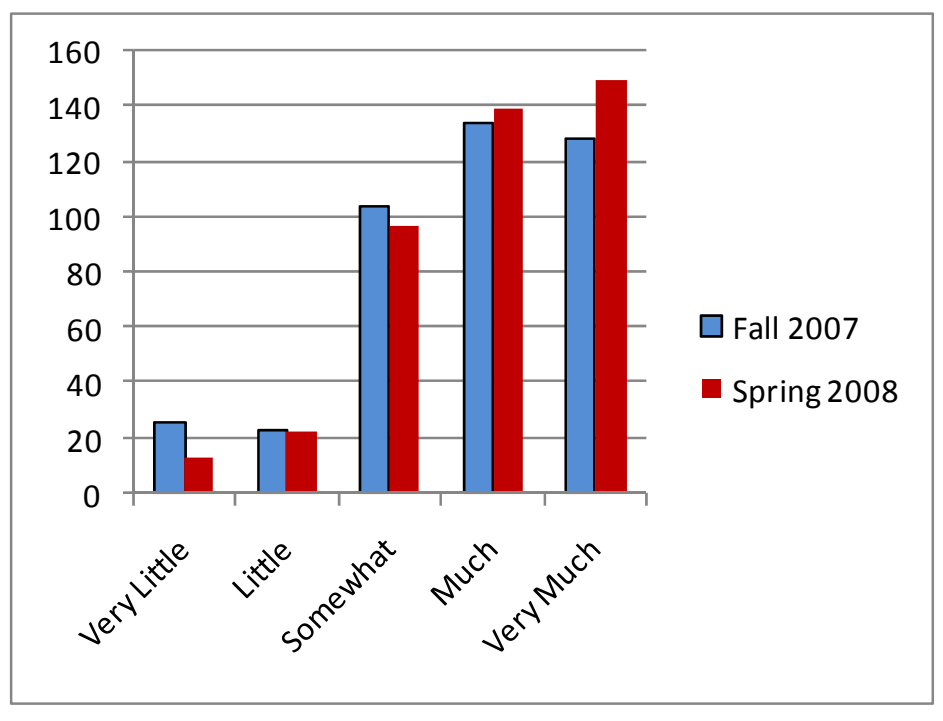

\section{Summary and Conclusions}

The integration of communication skills into the engineering curriculum has more than compensated for the loss of a standalone technical writing course; however, this process was augmented by the establishment of the Communication across the Curriculum program. Both faculty and students agree that their communication skills were improved by completing a communication-intensive course. Students also indicated that their communication deficiencies were broader than simply writing. Assessment of faculty showed that workload increased for both faculty and students in these courses; however, it was also acknowledged that students' knowledge of traditional course content was enhanced. In addition to the incentive provided by better understanding of course content, recognition of LSU Distinguished Communicators has provided an incentive for students to achieve the same skill level.

Another reason for the success of the $\mathrm{CxC}$ program in the $\mathrm{COE}$ stems from the fact that the program was built from grass root faculty's perceptions of student needs rather than from a topdown decree by the administration. The $\mathrm{CxC}$ program and the ECS comprise a sustained support system for engineering students and faculty, which has contributed to enthusiastic acceptance of these programatic changes by both faculty and students. At a cost comparable to supporting the technical writing of the past, and with the discipline specific context of these broader communication elements, it is projected that this curricular model ties more strongly to the ABET communication requirement. Initial indications are also positive that this will lead to a better outcome. 


\section{References}

[1] Engineering Accreditation Commission, Criteria for Accrediting Engineering Programs Effective for Evaluations During the 2005-2006 Accreditation Cycle, Accreditation Board for Engineering and Technology, Inc., Report, Nov. 2004.

[2] National Association of Colleges and Employers (NACE), Job Outlook 2009—Student Version [Online], Available: http://www.jobweb.com/studentarticles.aspx?id=2121, [cited Feb. 2009].

[3] Boeing Corporation, "Desired Attributes of an Engineer," [Online], Available: http://www.boeing.com/ companyoffices/pwu/attributes/attributes.html, [cited Feb. 2009].

[4] Department of Labor, Occupational Outlook Handbook (OOH), 2008-09 Edition, U.S. Bureau of Labor Statistics, [Online], Available:

http://www.bls.gov/oco/ocos027/home.htm\#training, [cited Feb. 2009]. 